\title{
Feasibility of Ground Testing A Moon And Mars Surface Power Reactor In EBR-II
}

\section{Space and Technology and Applications International Forum 2006}

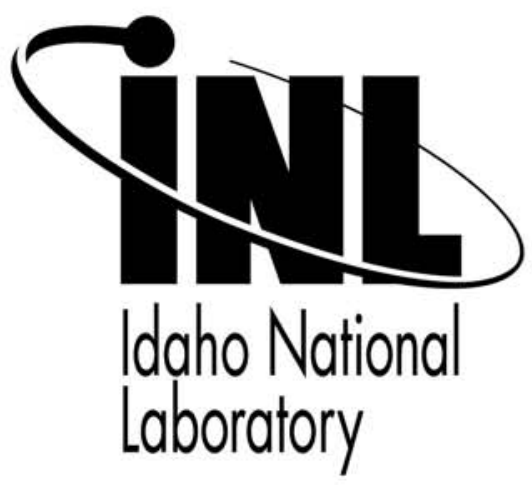

This is a preprint of a paper intended for publication in a journal or proceedings. Since changes may not be made before publication, this preprint should not be cited or reproduced without permission of the author. This document was prepared as an account of work sponsored by an agency of the United States Government. Neither the United States Government nor any agency thereof, or any of their employees, makes any warranty, expressed or implied, or assumes any legal liability or responsibility for any third party's use, or the results of such use, of any information, apparatus, product or process disclosed in this report, or represents that its use by such third party would not infringe privately owned rights. The views expressed in this paper are not necessarily those of the United States Government or the sponsoring agency. 


\title{
Feasibility of Ground Testing a Moon and Mars Surface Power Reactor in EBR-II
}

\author{
Sheryl L. Morton ${ }^{1 \mathrm{a}}$, Carl E. Baily ${ }^{1 \mathrm{~b}}$, Thomas J. Hill ${ }^{\text {lc }}$, and James E. Werner ${ }^{1 \mathrm{c}}$ \\ ${ }^{l a}$ Nuclear Materials Disposition and Engineering Department, ${ }^{1 b}$ Engineering, Design, \& Drafting Department, and \\ ${ }^{1 c}$ Space Nuclear Systems and Technology Department, Idaho National Laboratory, Idaho Falls, ID 83415 \\ 1a208-526-8247, Sheryl.Morton@inl.gov
}

\begin{abstract}
Ground testing of a surface fission power system would be necessary to verify the design and validate reactor performance to support safe and sustained human exploration of the Moon and Mars. The Idaho National Laboratory (INL) has several facilities that could be adapted to support a ground test. This paper focuses on the feasibility of ground testing at the Experimental Breeder Reactor II (EBR-II) facility and using other INL existing infrastructure to support such a test. This brief study concludes that the INL EBR-II facility and supporting infrastructure are a viable option for ground testing the surface power system. It provides features and attributes that offer advantages to locating and performing ground testing at this site, and it could support the National Aeronautics and Space Administration schedules for human exploration of the Moon. This study used the initial concept examined by the U.S. Department of Energy Inter-laboratory Design and Analysis Support Team for surface power, a lowtemperature, liquid-metal, three-loop Brayton power system. With some facility modification, the EBR-II can safely house a test chamber and perform long-term testing of the space reactor power system. The INL infrastructure is available to receive and provide bonded storage for special nuclear materials. Facilities adjacent to EBR-II can provide the clean room environment needed to assemble and store the test article assembly, disassemble the power system at the conclusion of testing, and perform posttest examination. Capability for waste disposal is also available at the INL.
\end{abstract}

Keywords: Surface power reactor, INL, nuclear, Moon, Mars, space.

PACS: 07.87.+v.

\section{INTRODUCTION}

A surface fission power system would need to be qualified to support extended space and specific surface exploration missions. Ground tests would demonstrate long-term performance of critical system parameters when placed under conditions that simulate the unique environments of the Moon and Martian surfaces. A test facility is needed to simulate these unique environments. This study evaluated the Experimental Breeder Reactor II (EBR-II) building features and associated infrastructure as a possible facility to perform ground test activities.

\section{BACKGROUND AND PURPOSE}

The National Aeronautics and Space Administration (NASA) is responding to the President's Vision for Space Exploration with a plan to return to the Moon, continue on to Mars, and extend a human presence in the solar system. Such a plan requires a human and robotic program supported by innovative technology and infrastructure.

Under the program named Constellation Systems, NASA is developing the Crew Exploration Vehicle (CEV) and related exploration architecture systems needed to send astronauts to the Moon and form the basis for exploring Mars and other destinations. The Vision for Space Exploration sets a goal of developing a CEV to land astronauts on the Moon by no later than 2020. Constellation Systems will provide the capabilities necessary for humans to travel and explore the solar system including Earth-to-orbit, in-space, and surface transportation systems; surface and space-based infrastructures; power generation; communications systems; maintenance and science instrumentation; and robotic investigators and assistants (NASA, 2005). 


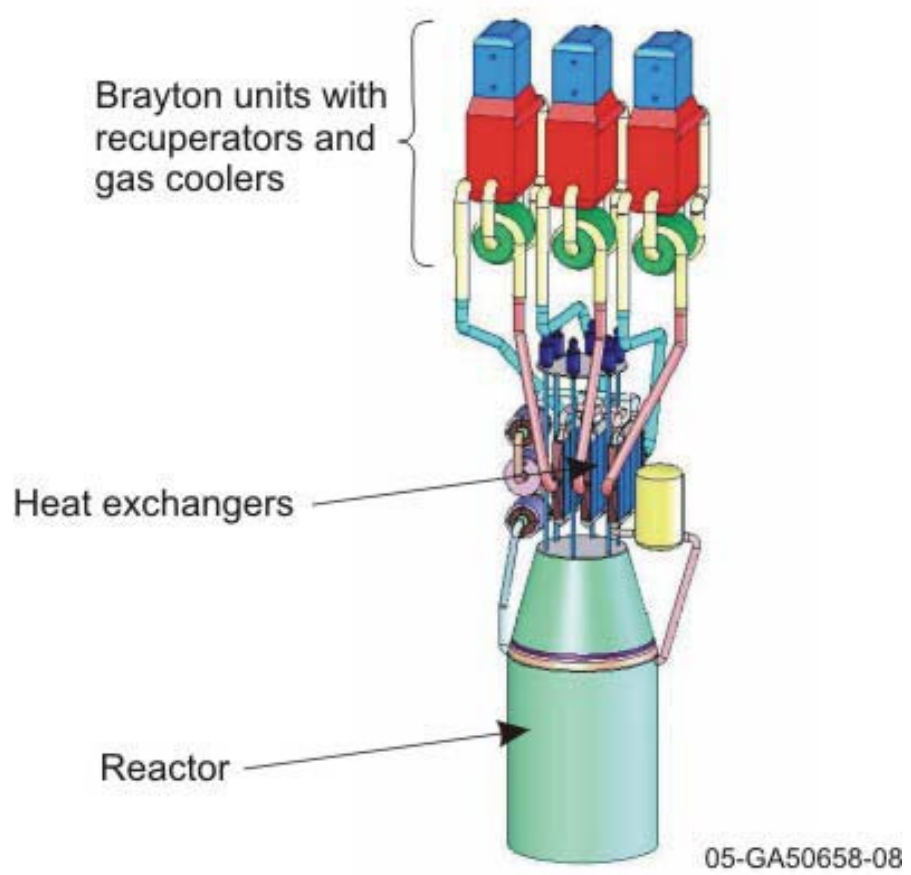

FIGURE 1. Test Article of the Liquid Metal-Brayton Three-Loop System.

The U.S. Department of Energy Inter-laboratory Design and Analysis Support Team has examined an initial concept for a surface power fission reactor to power human habitat on the Moon and Mars, a low-temperature, liquid-metal, three-loop Brayton power system (Figure 1). Heat generated in the liquid metal reactor would be transported to three heat exchangers that are each connected to a separate Brayton turbo machinery unit (with recuperator). The HeXe working fluid in the Brayton loops would be heated by the reactor coolant and cooled by a gas cooler for each loop. This power system concept is an example of what might be used as a surface power reactor design, and it was used to examine the feasibility of EBR-II as a potential test facility.

To qualify it for Moon and Mars missions, the surface power system would undergo extensive ground testing to evaluate the reactor and its controls, integrated power systems, and its materials and power converters. The unique environments of both the Moon and Mars would require an environmental and vacuum chamber that could simulate atmosphere, temperature, and regolith shielding conditions. A surface test facility must be able to receive and provide bonded storage for special nuclear materials, make available a clean room environment to assemble the test article prior to testing, install the test article in an environmental chamber, perform the required tests, perform disassembly and posttest examination, and provide disposal and storage capabilities.

\section{IDAHO NATIONAL LABORATORY FACILITIES AND CAPABILITIES}

An Idaho National Laboratory (INL) team examined the EBR-II, its supporting infrastructure, and its nuclear fuel cycle expertise as a potentially cost-effective and timely alternative to perform the required ground tests and support implementation of the Vision for Space Exploration goals. EBR-II was chosen for this study because it originally housed a test and demonstration sodium-cooled fast reactor as a complete power plant with an integral fuel cycle facility that could provide the components and systems needed for a ground test.

\section{Experimental Breeder Reactor II}

The EBR-II reactor building is a steel cylindrical structure with a hemispherical top closure and a semi-ellipsoidal bottom closure that was completed in 1963. The building has an $80-\mathrm{ft}$ inside diameter and a total height of approximately $146 \mathrm{ft}$, with about $48 \mathrm{ft}$ being belowgrade. Material for the building shell is 1 in. thick, ASTM 201, 
Grade B, fire-box quality carbon steel with all double-butt welded joints. The entire reactor building is supported on concrete placed directly on bedrock. A reinforced concrete shield lines the inside of the reactor building shell. This shield is $12 \mathrm{in}$. thick between the operating floor and the top of the cylindrical portion of the building. It then tapers down to 4-1/2 in. thick around the rest of the top closure. The building consists of three main floor levels: the subbasement floor, the basement floor, and the operating floor.

EBR-II operated from 1964 until 1994 as a test and demonstration sodium-cooled fast reactor and complete power plant with an integral fuel cycle facility. EBR-II was a DOE Category A reactor rated at $62.5 \mathrm{MW}(\mathrm{t})$ power and supplied a local grid with 20 MW electrical power. When it was shut down in 1994, the reactor, reactor systems, power plant, support systems, and facilities were in excellent operating condition. The reactor building and most support facilities have been continually maintained because they are used by other programs and are integral to the operation of the site.

The fuel was removed from EBR-II, and the primary and secondary sodium were removed from the facility and passivated onsite. The Plant Closure Project was completed in 2002 and left EBR-II in an industrially and radiologically safe condition. The EBR-II reactor building is now classified as a radiological facility with no high radiation levels in any accessible facility area. There are currently no plans or identified uses for the building and power plant other than small, short-term material sampling projects, which would not interfere with ground testing.

The "clean closed" status of the facility is governed by the Resource Conservation and Recovery Act (RCRA) operating permit issued by the Idaho Department of Environmental Quality. One of the 23 projects required for clean closure would need to be completed prior to the construction of a ground test facility.

Several key features of the INL site and EBR-II reactor building contribute to the feasibility and attractiveness of using this site for reactor ground testing. These include the following:

- EBR-II can be reclassified as a Category B nuclear facility to support the ground test.

- The reactor containment structure is in excellent condition; containment isolation systems are in place and can be reactivated with some reconditioning of containment isolation valves.

- Most EBR-II support systems are either operable or can be reactivated as necessary.

- The EBR-II control room can be reestablished as a functional reactor control room and data acquisition center.

- INL safeguards and security personnel are experienced in securing Category I nuclear materials.

- Operational hot cell facilities at INL can handle irradiated nuclear fuel examination and storage.

- A complete infrastructure resides at INL to support the operation and maintenance of a nuclear reactor system including facilities, capabilities, and personnel.

- INL personnel are experienced in reactor and nuclear facility operations, maintenance, engineering, and radiological support; handling of alkali metal systems, primarily sodium and $\mathrm{NaK}$; and permitting facilities for the handling, treatment, and storage of radiological and mixed waste.

\section{Other INL Support Facilities}

Several existing INL facilities could provide support functions for ground testing of a surface reactor test article at EBR-II.

The Fuel Conditioning Facility (FCF) is an air and argon hot cell facility. The air cell is used to handle, store, assemble, and disassemble components. The much larger argon cell allows for work on materials that are adversely affected by oxygen. It has remote material handling capacity of 5 tons and up to $6 \mathrm{ft}$ in diameter by $8 \mathrm{ft}$ long. A passageway between FCF and EBR-II provides a means to transfer (by way of an airlock) two 18-ton interbuilding casks. It allows for assembly and disassembly of a test unit in an inert atmosphere and purging the system prior to being installed in the test chamber. It also provides safe and secure handling of the reactor during disassembly and postirradiation examination upon completion of a test program. 
The Hot Fuel Examination Facility (HFEF) is a versatile, modern air and argon hot cell facility that can perform postirradiation examination of reactor fuels and characterize and package spent fuel and radioactive waste, including high-level waste. It houses two shielded hot cells, the air atmosphere decontamination cell and the main argon gas atmosphere cell, and 21 workstations equipped with shielded windows and master-slave manipulators.

The Neutron Radiography Reactor Facility is a TRIGA [training, research, and isotope reactors (built by General Atomic)] research reactor that is located within the HFEF. It is equipped with two beam tubes and two separate radiography stations to perform radiography of irradiated and unirradiated reactor components.

The Fuel Manufacturing Facility supports the research and development of advanced fuel forms and contains one of the two Category I Materials Balance Area vaults. This facility can be used for receipt and storage of nuclear fuel for a surface reactor ground test article and test article assembly.

Other INL support facilities including the Radioactive Scrap and Waste Facility, the Contaminated Equipment Storage Building, Analytical Laboratory and Electron Microscopy Laboratory, Sodium Components Maintenance Shop, and Radioactive Waste Management Complex are available for system disassembly and disposal at testing completion.

\section{FACILITY MODIFICATIONS}

The location within the EBR-II reactor building that was selected for the ground test assessment appears to provide suitable accommodation for a reactor test article and support systems. The location has space for shielding, remote handling equipment, support systems, proximity to the equipment access hatch in the containment dome, proximity to the equipment transfer tunnel, minimal interference with integral building features, and relatively minor interference with installed systems. Some structural modifications to the EBR-II reactor building would be required, but the identified location appears to have the least impact and makes the best use of the available space in the reactor building.

Figure 2 shows a test reactor located in the northeast quadrant of the containment building near the equipment transfer tunnel. The operating and basement floors in this area are reinforced concrete slab supported by a series of reinforced concrete beams, columns, and walls that extend to the sub-basement floor. The sub-basement floor is formed by solid concrete extending to the bottom of the steel containment shell. An opening in the operating floor would be made to accommodate the test article.

The reactor is shielded and is below the reactor operation floor to allow personnel access to the EBR-II containment building during the ground test operation. The reactor test article would be located adjacent to, and make use of, a portion of the existing EBR-II biological shielding. The EBR-II reactor primary tank and equipment are still installed within the biological shielding but are not shown in Figure 2. The 75-ton polar crane can position the test article and transport other equipment within the containment as required.

Secondary system dump heat exchangers would be located adjacent to the containment building. The vacuum cryopumps would be located within an existing shielded area previously used for the reactor primary sodium purification system. The remaining vacuum system components would be located outside the shielded area. After completion of testing, the reactor core would be removed with remote manipulators and other remote handling equipment located within the shielding cask. The core would be placed in the equipment transfer tunnel and then transported through the tunnel to FCF for subsequent storage, inspections, or disassembly. After disassembly, components of interest would be transported to HFEF for examination.

Assuming a prototype reactor similar to the one shown in Figure 1, the reactor test article mass and shielding are roughly estimated to be 15 metric tons. There may be additional concrete radiological shielding around the reactor and environmental chamber to ensure an adequate biological barrier. It is assumed that additional columns and walls would need to be installed to transfer the weight to the sub-basement floor.

Shielding design would rely on shielding calculations to save mass and space, neutronics analysis to prevent a design with an unacceptable amount of coupling between the facility structure and the reactor core, and structural analysis to verify that the test setup is stable and meets operational and safety requirements for the test. 

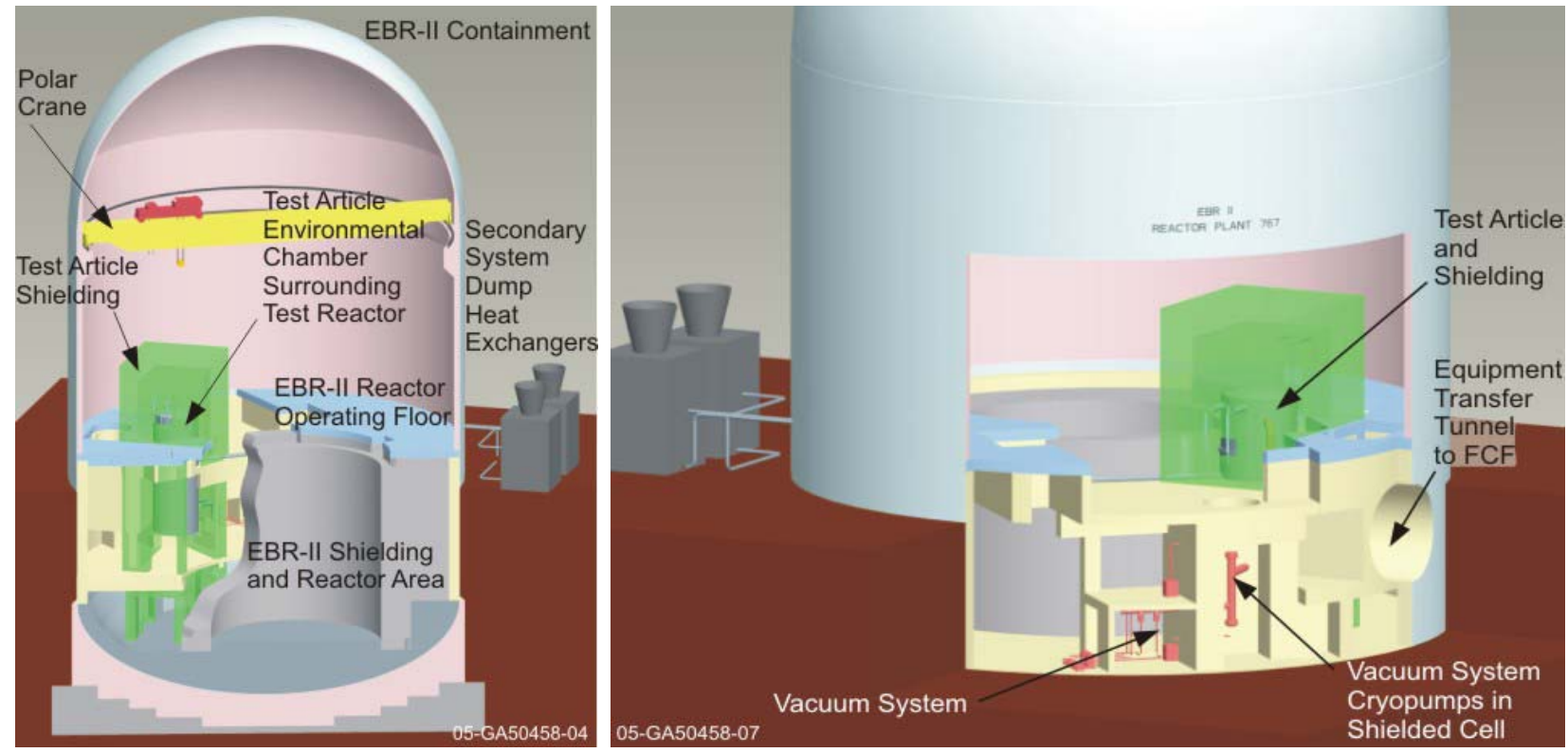

FIGURE 2. Test Article in Proposed Location in EBR-II.

The Radioactive Sodium Chemistry Loop (RSCL) structure is located between the basement floor and operating floor in the general area proposed for the test article location. The RSCL is a series of cells constructed of steel beams and columns with shield walls and ceilings. It would be removed under a RCRA project to make room for installation of the test article. Figure 3 shows an outline of the RSCL structure and the projected interference with the test article. It is assumed that everything can be removed from the RSCL cells and that radiation levels are low enough to allow access to all RSCL components.

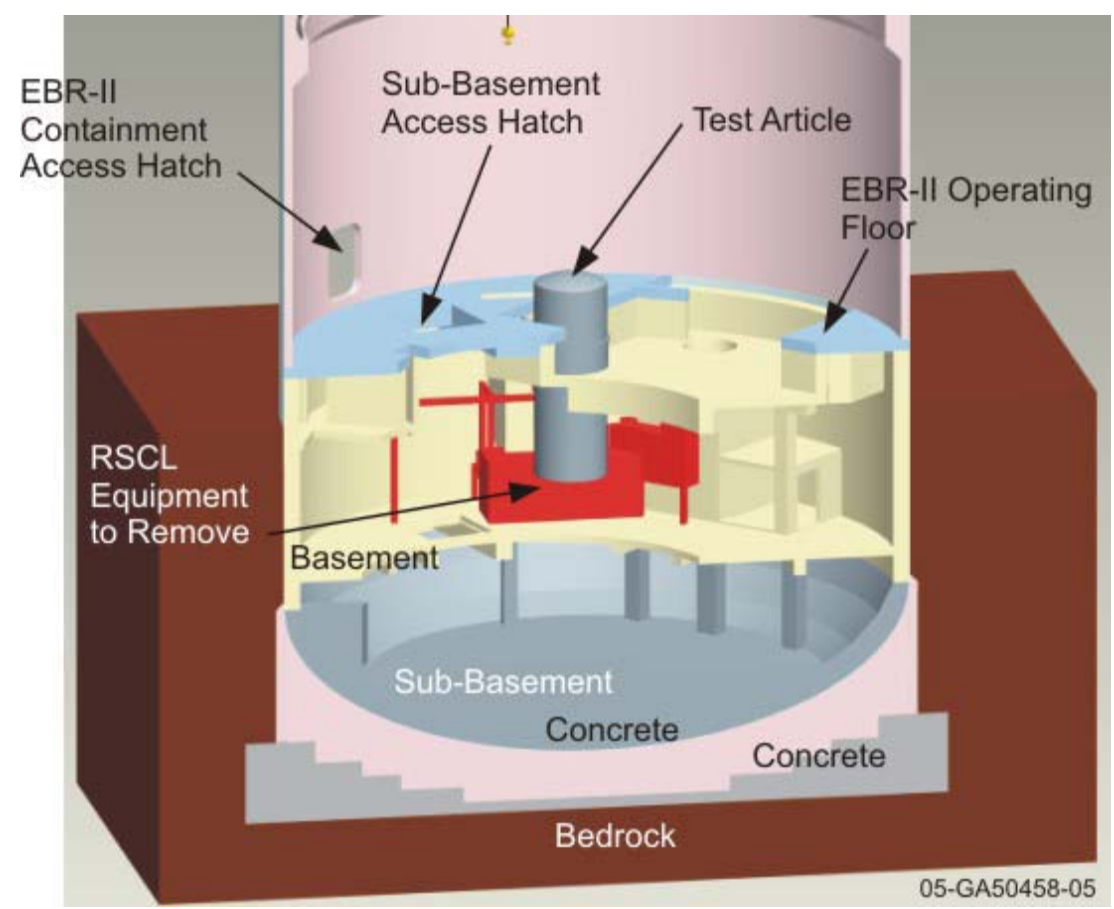

FIGURE 3. Outline of RSCL to Be Removed Prior to Installing Ground Test Equipment. 


\section{FACILITY AND SYSTEM REQUIREMENTS}

Specialized systems and components would be provided or developed prior to surface power testing in EBR-II as discussed in the following subsections. In addition, INL would supply normal and standby electrical power systems to support operation of the test article. Normal operating power is available up to $20 \mathrm{MW}$ from existing electrical substations originally installed to support EBR-II. Additional systems would supply standby power to support critical equipment during emergency conditions. EBR-II would be equipped with the service systems necessary to facilitate the construction, operation, and post-test activities of the reactor ground test (e.g., water systems, compressed air, waste systems, heating and ventilation, fire protection, and physical security).

\section{Environmental Chamber and Vacuum System}

An environmental chamber and a means to evacuate the chamber would be used for testing the reactor system to create an environment that simulates both space and the atmosphere of Mars and contains a minimum amount of gases that could react with the reactor system materials of construction. It would provide reliable long-term operation (24 months or longer as required) at a pressure of $1.3 \times 10^{-6} \mathrm{~Pa}\left(1.0 \times 10^{-8}\right.$ torr). The chamber design would permit installation of the complete surface power system as one assembly, with means for remotely connecting instrument and power cables. There would be capability for removing the surface power system assembly after it becomes radioactive. The following components and systems would be included in the environmental test chamber and vacuum system:

- An environmental and vacuum test chamber to simulate conditions in space and in the atmosphere of Mars.

- A vacuum pumping system to reduce the pressure and control the level of reactive gases in the test chamber.

- A test chamber cooling system to remove heat generated by gamma and neutron heating, as well as thermal radiation from the test article.

- A chamber bakeout system to heat the vessel and drive residual gases from the surfaces of the test chamber and the test article, thereby minimizing subsequent off gassing of the surfaces.

- Heating and cooling parameters would be established to simulate the Moon and Mars conditions in the test chamber as needed prior to operations.

- Shielding designs for neutron and gamma reflection would be incorporated into the design to simulate proposed shielding designs for specific surface applications.

- Synthetic quantities of Moon or Mars regolith material would be used to simulate surface reflection as well as any material activation or particulate environments to which the reactor system may be exposed. Figure 4 provides conceptual drawings of how a test with simulated regolith could be conducted. The geometry of the regolith can reflect a variety of biological shielding configurations as needed. The test configuration shown on the right of Figure 4 would assume that the reactor is placed in a small crater with the reactor at least $5 \mathrm{ft}$ above the surface due to the descent module.

- A secondary heat rejection system through the primary heat exchanger to dissipate a minimum of $500 \mathrm{~kW}(\mathrm{t})$ of the bulk of the reactor power.

- A residual heat removal system to cool the reactor during loss of cooling or other upset events that must remove approximately $4 \%$ (or $\sim 20 \mathrm{~kW}$ ) of reactor decay heat in various off-normal conditions.

\section{Liquid-Metal Handling}

INL would provide facilities for receiving and purifying primary, secondary, and auxiliary liquid-metal coolant; filling the primary, secondary, and auxiliary loops with liquid metal; and verifying purity during system operation. These facilities would be capable of removing the liquid metal from the primary and secondary systems upon ground test completion. Facilities would be designed to address the safety considerations of working with the alkali metals. 

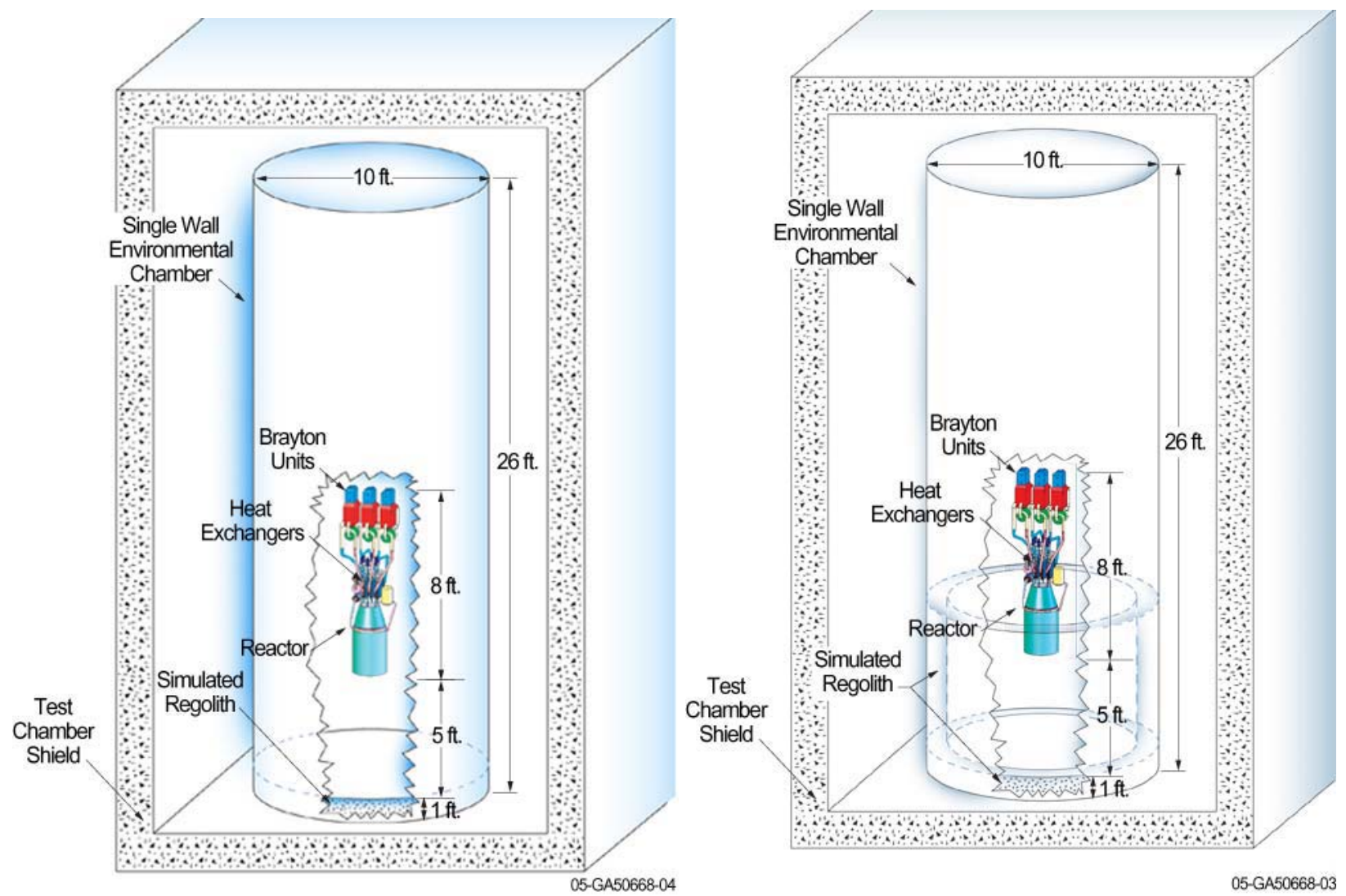

FIGURE 4. Simulated Regolith Configurations for Surface Reactor Ground Testing.

\section{Instrumentation, Control, and Data Acquisition}

The test reactor system designer would provide the reactor and primary cooling system controls, and INL would provide the interfaces to the control room and a data acquisition system with monitors in the control room. Care would be taken to preserve the National Historical Register requirements of the room.

An instrumentation plan for monitoring facility operation would be developed and integrated with the instrumentation supplied by the reactor system designer for the test reactor article. The control console would be designed using appropriate human factors and standards and would include the following functions:

- Reactor and primary heat transport instrument readouts (e.g., thermocouple and neutronic measurements)

- Facility system controls and control instrument readouts (e.g., secondary heat transport, environmental controls, vacuum, inert gas, emergency heat removal, and plant protection system).

\section{Reactor Fuel Loading}

Equipment and procedures would be developed to facilitate fueling the reactor. This activity would require the development and installation of a variety of handling fixtures and devices. This equipment would be designed so that as much as possible could also be reused to defuel the reactor at end-of-life.

The reactor test article is assumed to be shipped to INL without the nuclear fuel loaded in the core. Once the reactor test article has been received at EBR-II and preparations for installation are complete, the fuel would be loaded into 
the reactor core. Final closure welds and inspections of the reactor test article would be made by the reactor system designer prior to completing installation of the reactor test article in the vacuum vessel. Handling fixtures and tooling necessary for fuel loading would be provided by the reactor system designer.

\section{Test Article Removal Remote Handling Equipment}

At the end of the operating period, the environmental chamber and reactor vessel would be disassembled and discarded as radioactive and contaminated waste. The decontamination and decommissioning of the environmental chamber and reactor vessel would require specialized remotely operated equipment. Some of this equipment would be integrated into the design of the hot cell to aid in minor maintenance and operational issues. Other equipment would be designed specifically for the end-of-life disassembly of the equipment to limit the amount of equipment inside the hot cell.

\section{Shielding}

The reactor system designer would design the reactor system shields to simulate the shielding that would be used on the Moon and Mars. The system shields would surround the reactor core, vessel, and reflector and protect the radiation sensitive components of the reactor. Neutron and gamma reflection may be addressed with a simulated regolith shield within the test chamber made to simulate the Moon and Mars surfaces as shown in Figure 4.

The bottom of the bulk shield for this reactor is assumed to be $5 \mathrm{ft}(1.5 \mathrm{~m})$ above the surface regolith. It is assumed that the reactor will sit on the descent module with the descent engines located directly below the reactor. The distance to the ground is taken into account for this study.

In addition, INL would work with the reactor system designer to construct adequate biological shielding to supplement the neutron and gamma system shields surrounding the test article, limit the radiation exposure accumulated by personnel, and to limit the activation of the test facility. The space between the test article and shielding would include a HEPA-filtered ventilation system to prevent the accumulation of activated gases in the containment building. Existing biological shielding from the EBR-II reactor would also be used.

\section{CONCLUSION}

Ground testing a surface power fission reactor at the INL is feasible to support the Vision for Space Exploration of the Moon, Mars, and beyond. The existing EBR-II containment is a suitable location for ground testing and initial evaluations show that this location and the existing infrastructure at INL can provide the clean room environment needed to assemble and store the test article assembly, disassemble the power system at the conclusion of the test, perform posttest examination, and provide waste disposition. The INL can support NASA schedules for human exploration of the Moon leading towards fulfillment of the Vision.

\section{ACKNOWLEDGMENTS}

This work was supported by the U.S. Department of Energy, Office of Nuclear Energy, Science, and Technology (NE) for NASA's Project Prometheus under DOE-NE Idaho Operations Office Contract DE-AC07-05ID14517. The views represented in this paper are those of the authors and are not necessarily representative of DOE or NASA.

\section{REFERENCES}

National Aeronautics and Space Administration, “Exploration Systems Mission Directorate,” (2005), http://exploration.nasa.gov/, September 27, 2005. 